\title{
«Dantes Inferno» - psykologisk førstehjelp ved postoperativt delirium
}

\author{
Så våknet jeg opp i helvete, omgitt av ondskap og brutalitet. Det er det grusomste jeg noensinne har opplevd. \\ Så mye frykt, så mye lidelse, rundt meg er bare brutale ansikter og folk som blir torturert. Jeg er fryktelig redd.
}

Elin Fjerstad

elin.fjerstad@diakonsyk.no

Nina Lang

Ordene tilhører en kvinne i 50-årene. Etter et kirurgisk inngrep våkner hun opp og er overbevist om at hun er i helvete. Diagnosen er postoperativt delirium - en akutt forvirringstilstand etter kirurgi.

\section{Alvorlige konsekvenser}

Postoperativt delirium kjennetegnes ved endret bevissthetsnivå, nedsatt oppmerksomhet, forstyrret tenkning, ulogisk og usammenhengende tale, hallusinasjoner og svekket vurderingsevne $(1,2)$. Symptomene utvikles vanligvis i løpet av de fire første dagene etter et kirurgisk inngrep (1), og pasienten kan tidvis fremstå helt adekvat, for så å vise manifeste symptomer. Postoperativt delirium er en underdiagnostisert og underrapportert komplikasjon som har alvorlige konsekvenser: høy dødelighet, større behov for medisinsk behandling og lengre liggetid på sykehus (2). En av ti pasienter som har vært igjennom et intensivopphold av mer enn 48 timers varighet, utvikler posttraumatisk stresssyndrom (PTSD) (3). Risikoen for å utvikle syndromet øker dersom fragmentariske minner, mareritt og hallusinasjoner gjør det vanskelig for pasientene å forstå hva som skjedde med dem, og de i ettertid ikke kan fortelle en sammenhengende historie om hendelsesforløpet. Dette er vanlige følger av postoperativt delirium, men det kan forebygges med psykologisk førstehjelp.

\section{Dantes Inferno - \\ fra helvete til høye hæler}

Caroline ble innlagt og operert for akutt abdomen, hvor tarmen ble lagt ut. På grunn av omfattende postoperative komplikasjoner, ble hun lagt i kunstig koma. Da hun ble vekket, var hun forvirret og ute av stand til å kommunisere på grunn av respiratorbehandlingen. Det eneste hun visste var at hun var i stor fare - ikke på grunn av kritisk sykdom, men fordi hun trodde at hun ble holdt fanget, omgitt av ondskap og brutalitet.
Caroline bruker eposet Dantes Inferno for å beskrive hvordan hun hadde det. Dante reiser gjennom helvete, via skjærsilden og til Paradiset.

Så våknet jeg opp i helvete og det er det grusomste jeg noensinne har opplevd. Jeg befinner meg i en fangeleir i Latin-Amerika, det er helt forferdelig, mye frykt og lidelse, rundt meg er bare brutale ansikter og folk som blir torturert. Det ene scenario verre enn det andre. På et tidspunkt er jeg fanget $i$ et katolsk nonnekloster, og jeg var i Midtøsten, Nord-Afrika, Beirut, Arabia, og jeg var ikke velkommen noen steder. Dem jeg møtte var brutale og undertrykkende. Men, så en dag, midt iblant de brutale ansiktene, ser jeg endelig et kjent ansikt - min kjære eksmann. Det er en enorm lettelse - endelig kom redningen. Min idé var at han hadde planlagt en redningsaksjon for å få meg ut av fangenskap. Samtidig forsto jeg at jeg ikke måtte vise gleden min for da ville fienden (helsepersonell) forstå at noe var på gang. Derfor begynte jeg å spille med og bli en medgjørlig pasient, ikke stritte imot $i$ stell slik jeg hadde gjort før. Det som for pleierne sikkert så ut som om jeg begynte å bli bedre, var egentlig en del av planen for å komme meg ut av fangenskapet.

Caroline beskriver typiske symptomer ved postoperativt delirium, dramatiske scener som gir opphav til sterke følelser, frykt og panikk $(4,5)$. Det er som å drømme i våken tilstand, eller som å være i et våkent mareritt.

\section{Det kliniske bildet}

I journalen beskrives Caroline som urolig og stresset; hun ville ut av sykehuset, husket ikke at hun var operert og hadde snøvlete, uklar tale. Hun var vanskelig å få kontakt med, lite samarbeidsvillig, virket stadig mer redd, kavet og grep etter ting i rommet som ikke var der, var ukritisk og ikke orientert for tid og sted. Den 14. dagen etter operasjonen fremsto hun som klar og orientert, men virket nedstemt og lei. Hun fikk tilbud om antidepressiv medikasjon, men takket nei. Under den rutinemessige oppfølgingssamtalen ble det ikke snakket om symptomene hennes på en slik måte at hun forsto at det hun hadde opplevd hadde et navn, var forårsaket av medisinske forhold, og at hun kunne få hjelp til å håndtere opplevelsene sine.

\section{Psykologisk førstehjelp}

Carolines historie illustrerer hvor intenst skremmende et postoperativt delirium oppleves. Hva kan bidra til å skape trygghet og til å forebygge psykiske plager i etterkant?

\section{Berolige og trøste}

Kvalitative studier viser at behandlerne som forsøker å forstå pasientens situasjon, lytte og trøste reduserer frykten (4). Personalet på intensivavdelingen så at Caroline var veldig redd, men forsto ikke hvorfor. De opplevde at hun kun kortvarig lot seg berolige. Når bevissthetsnivået svinger og tenkningen forstyrres, er det naturlig at effekten av beroligelse er kortvarig, men det er ikke desto mindre viktig. Caroline fikk ro og skjerming, og hadde et fast team rundt seg. Til tross for at personalet fulgte anbefalinger om å ha en fastvakt (6) og ellers gjorde det de kunne for å hjelpe, ble oppholdet svært belastende for henne. På spørsmål $i$ ettertid om hva som ville ha hjulpet henne, svarer hun:

Det hadde hjulpet om de hadde holdt litt rundt meg, strøket meg og vært nær slik man er mot et lite barn som er redd. De tok jo på meg fordi de måtte i stell og slikt, men jeg opplevde det som om de herjet med kroppen min liksom. Isteden burde de ha tid til å ta på pasienten med silkehansker.

Caroline opplevde at det var utrygt når helsepersonell snakket med hverandre over hodet på henne. Det samme trekkes frem i kvalitative studier; å bli snakket om, men ikke til, forsterker pasienters frykt (7).

\section{Lage sammenheng i kaoset}

Caroline opplevde smertene og den hardhendte behandlingen som brutal, men var det fangevokternes brutalitet i LatinAmerika eller var hun på sykehuset? Var legene og pleierne snille, eller var de egentlig ute etter å ta livet hennes? Vrangforestillinger, hallusinasjoner og fragmentariske minner gjør at det er vanskelig for pasienten å forstå hva som faktisk har skjedd, og det øker risikoen for å utvikle 


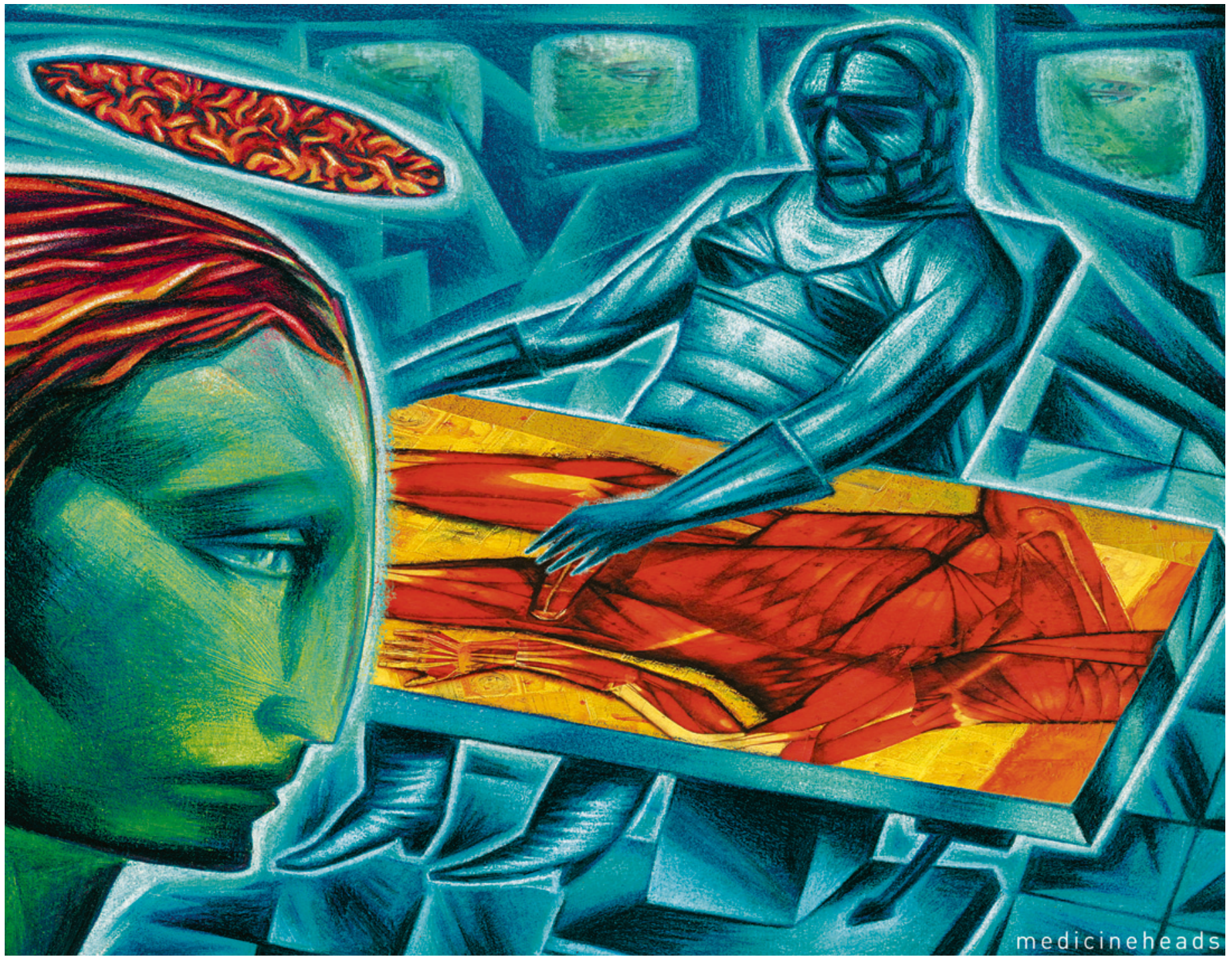

Illustrasjon @ Trond Nordahl/medicineheads

posttraumatisk stresssyndrom. Det er derfor viktig å gi pasienten en sammenhengende historie. Konkret informasjon om hendelsesforløpet gjør det lettere for pasienten å fylle hull i hukommelsen, sortere opplevelsene og sette deliriets opplevelser inn i en kontekst.

Informasjon om sykdom og symptomer Sykdomsinformasjon er viktig for mestring generelt, og for pasienter som har opplevd postoperativt delirium spesielt. Pasienten trenger å få vite at postoperativt delirium er en relativt vanlig komplikasjon som kommer til å gå over:
«Disse symptomene som du har hatt med mareritt og veldig skremmende og vonde tanker og bilder i hodet, betyr at du har hatt det som heter postoperativt delirium. Det er en vanlig komplikasjon etter et kirurgisk inngrep, og det betyr ikke at du holder på å bli gal. Vi vet ikke helt nøyaktig hva som er årsaken, men det finnes behandling, og det kommer til å gå over. Vi vet mye om hva som kan hjelpe deg, og den hjelpen skal vi gi deg.»

Caroline hadde sterk angst og «flashbacks» da hun kom til sykehusets klinisk helsepsykologiske tilbud fire uker etter utskrivningen. Hun var da i ferd med å tolke sine egne reaksjoner og tanker som galskap, isolerte seg og slet med å mestre tilværelsen. Skam- og skyldfølelser over egen oppførsel, og angst for at andre skal tro man er blitt gal, er beskrevet i kvalitative studier hos pasienter etter postoperativt delirium (4). Slike tanker og følelser kan føre til psykiske plager. Oppfølgingssamtaler der pasienten får konstruktive tilbakemeldinger på sine tanker og bekymringer, forebygger utvikling av psykiske plager.

«Mange som har vært gjennom det samme som deg, får tanker om at nå er de i ferd med å bli gale eller senile. Det er vanlig å tenke 
slik, men det er viktig å huske at du ikke holder på å bli gal. Å være engstelig nå, er en normal etterdønning etter alt du har vært igjennom.»

$\AA$ ta med seg denne setningen, gjør det lettere for pasienten å møte sine egne reaksjoner på en konstruktiv og støttende måte en liten intervensjon som kan gjøre en stor forskjell.

Dagbok

A skrive dagbok under opphold på intensivavdeling kan forebygge depresjon (8) og utvikling av posttraumatisk stressyndrom $(9,10)$. Det innebærer at pleierne fortløpende skriver ned hva som skjer med pasienten, eventuelt tar bilder og legger ved. Det hjelper pasienten å få oversikt, sortere hendelser og fylle hullene i hukommelsen. Også for pårørende kan det å skrive i dagboken ha en terapeutisk verdi. Det kan gjøre det lettere for pasient og pårørende sammen å bearbeide det som har skjedd i ettertid. Å skrive dagbok anbefales nå som et forebyggende tiltak for alle pasienter som er på en intensivavdeling i over 48 timer (11).

\section{Avslutning}

Postoperativt delirium er en medisinsk tilstand som kan gi store psykologiske etterdønninger. Psykologisk førstehjelp er avgjørende for at pasienten ikke bare overlever, men også blir i stand til å gjenerobre livet. Caroline var sterk nok til å se at hun trengte psykologisk behandling, modig nok til å be om det og heldig nok til å bli favnet av endringer som er på gang. Det er endringer som er ønsket av Helsedirektoratet og innført som en pilot ved Diakonhjemmet sykehus i Oslo - Prosjekt klinisk helsepsykologi. Fremveksten av fagfeltet klinisk helsepsykologi innebærer at psykologens kompetanse kommer til nytte også for mennesker med somatisk sykdom. Carolines historie er eksempel på helhetlig behandling i praksis. Selv sier hun det slik:

Skjærsilden kom tilbake til meg da det var tid for et nytt inngrep for å legge inn tarmen - tenk om jeg havnet i helvete på nytt! Det hadde jeg ikke overlevd uten å bli gal. Jeg hadde ikke turt å operere inn tarmen igjen uten samtalene jeg hadde med psykologen og anestesilegen sammen, eller uten at jeg visste at de samarbeidet godt med kirurgen. Jeg sliter fortsatt, men jeg har fått hverdagen min tilbake. Da er man i Paradiset. For mister man hverdagen, selv den grå og kjedelige, er det paradis å få den tilbake igjen - paradis å komme ut av joggebuksene og inn i høye hæler!

Pasienten har gitt samtykke til at artikkelen publiseres. Caroline er ikke pasientens virkelige navn.

\section{Elin Fjerstad (f. 1964)}

er psykologspesialist og arbeider ved Prosjekt klinisk helsepsykologi/Nasjonal behandlingstjeneste for revmatologisk rehabilitering, NBRR/Nasjonal kompetansetjeneste for revmatologisk rehabilitering, Diakonhjemmet sykehus. Har skrevet boken Frisk og kronisk syk. Et psykologisk perspektiv på kronisk sykdom. Forfatter har fylt ut ICMJE-skjemaet og oppgir ingen interessekonflikter.

\section{Nina Lang (f. 1970)}

er psykologspesialist og prosjektleder Prosjekt klinisk helsepsykologi, Psykiatrisk konsultasjonsteam, Diakonhjemmet sykehus. Forfatter har fylt ut ICMJE-skjemaet og oppgir ingen interessekonflikter.
Litteratur

1. Caraceni A, Grassi L. Delirium. Acute confusiona states in palliative medicine. New York: Oxford University Press, 2011.

2. Rudolph JL, Marcantonio ER. Review articles: postoperative delirium: acute change with longterm implications. Anesth Analg 2011; 112: 1202-11.

3. Davydow DS, Gifford JM, Desai SV et al. Posttraumatic stress disorder in general intensive care unit survivors: a systematic review. Gen Hosp Psychiatry 2008; 30: 421-34

4. Duppils GS, Wikblad K. Patients' experiences of being delirious. J Clin Nurs 2007; 16: 810-8.

5. Andersson EM, Hallberg IR, Norberg A et al. The meaning of acute confusional state from the perspective of elderly patients. Int J Geriatr Psychiatry 2002; 17: 652-63.

6. Juliebø V. Wyller TB. Delirium - en tilstand med høy forekomst og dårlig prognose. Geriatisk sykepleie 2010, 3: 4-6.

7. Fawdry K, Berry ML. Fear of senility: the nurse's role in managing reversible confusion. J Gerontol Nurs 1989: 15: 17-21

8. Knowles RE, Tarrier N. Evaluation of the effect of prospective patient diaries on emotional wellbeing in intensive care unit survivors: a randomized controlled trial. Crit Care 2009: 37: 184-91.

9. Jones C, Capuzzo M, Flatten M et al. ICU-diaries may reduce symptoms of posttraumatic stress disorder. Intensive Care Med 2008; 32: 144.

10. Jones C, Bäckman C, Capuzzo M et al. Intensive care diaries reduce new onset post traumatic stress disorder following critical illness: a randomised, controlled trial. Crit Care 2010; 14: R168.

11. National Institute of Health and Clinical Excellence. Rehabilitation after critical Illness: NICE clinical guideline 83(accessed January 1, 2011). London: National Institute of Health and Clinical Exellence, 2009. http://www.nice.org.uk/CG83 (19.4.2013)

Mottatt 14.2. 2013, første revisjon innsendt 22.3. 2013, godkjent 5.4. 2013. Medisinsk redaktør Hanne Støre Valeur. 